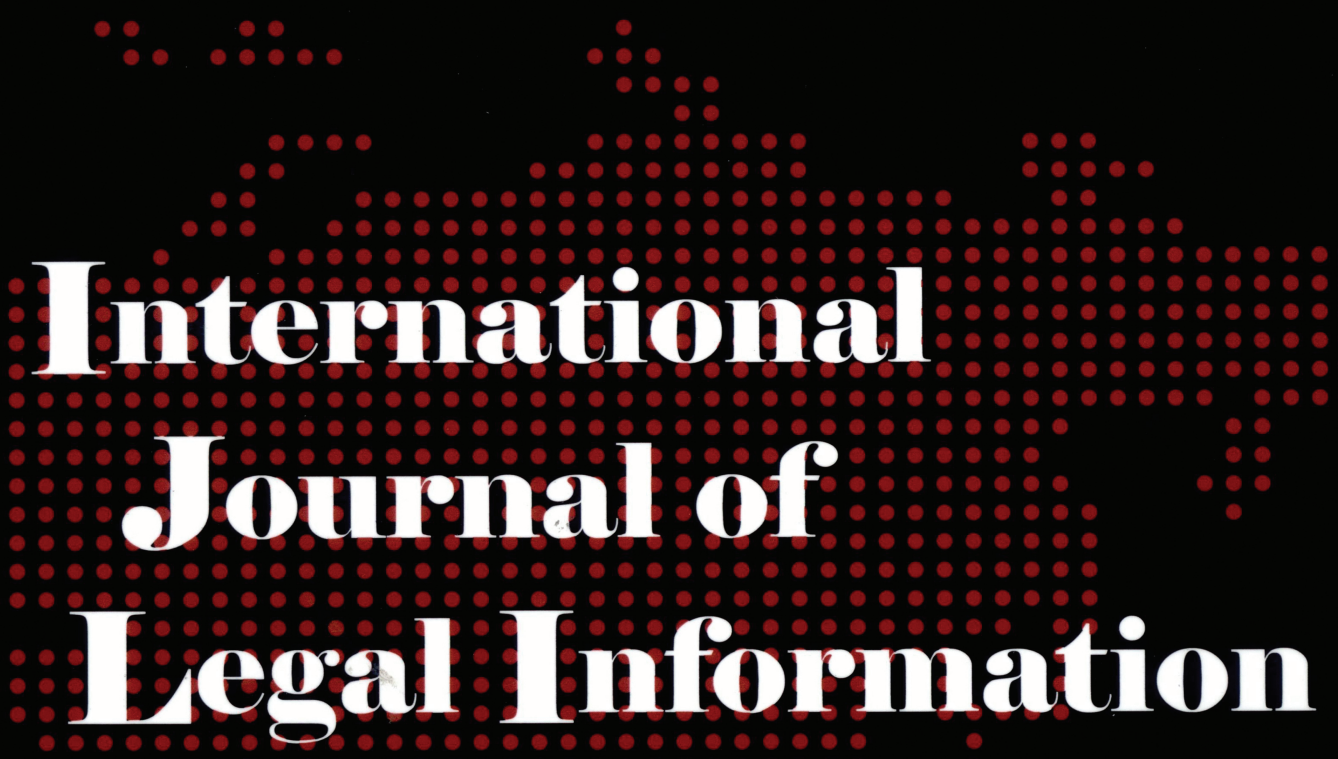

\title{
The Official Publication of
}

\section{The International Association of Law Libraries}

\author{
Printed and Distributed
}

Compliments of William S. Hein \& Co., Inc. 


\title{
INTERNATIONAL JOURNAL
}

\author{
of \\ LEGAL INFORMATION
}

VOLUME $43 \cdot$ Number $1 \cdot$ SPRING 2015

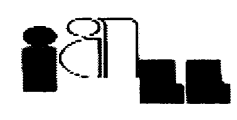

THE OFFICIAL JOURNAL OF THE

INTERNATIONAL ASSOCIATION OF LAW LIBRARIES http://www.iall.org 
ADVISORY COMMITTEE ON COMMUNICATIONS

Marci Hoffman (University of California, Berkeley), Chair Mark Engsberg (Emory University), Journal Editor

Mary Rumsey (University of Minnesota), Member at Large

Silke Sahl (Columbia University), Member at Large

Aslihan Bulut (Harvard University), Member at Large

Bård Tuseth (University of Oslo), Second Vice President

\section{INTERNATIONAL ASSOCIATION OF LAW LIBRARIES OFFICERS AND DIRECTORS,} 2013-2016

Jeroen Vervliet, President

Peace Palace Library

The Hague, Netherlands

Petal Kinder, Immediate Past President

High Court of Australia

Canberra, ACT, Australia

Ruth Bird, First Vice President

Bodleian Law Library

Oxford, England

Bård Tuseth, Second Vice President

University of Oslo

Oslo, Norway

Barbara Garavaglia, Secretary

University of Michigan Law Library

Ann Arbor, Michigan, USA

Xinh Luu, Treasurer

University of Virginia Law Library

Charlottesville, Virginia, USA

Mark D. Engsberg, Ex Officio

Hugh F. MacMillan Law Library

Emory University School of Law Atlanta, Georgia, USA

Marci Hoffman, Ex Officio

Berkeley Law Library

University of California Berkeley

School of Law

Berkeley, California, USA

Ivo Vogel

Staatsbibliothek zu Berlin

Berlin, Germany
Kristina Alayan

Duke University School of Law

Durham, North Carolina, USA

Daniel Boyer

Nahum Gelber Law Library

McGill University

Montreal, Quebec, Canada

Kurt Carroll

Library of Congress

Washington, DC, USA

Lily Echiverri

University of the Philippines

Espiritu Hall, Diliman

Quezon City, Philippines

David Gee

Institute of Advanced Legal Studies

University of London

United Kingdom

Kerem Kahvecioglu Istanbul Bilgi University

Istanbul, Turkey 


\section{PURPOSE AND EDITORIAL POLICY}

The International Journal of Legal Information, the official publication of the International Association of Law Libraries, is issued three times a year: Spring, Summer, Winter. It seeks to advance the exchange of legal information throughout the world. Under the direction of its international editorial board and advisors, the $I J L I$ serves the global community of law librarians, legal scholars, and practitioners through the publication of original articles, conference papers, bibliographies, book reviews, documents concerning law and law-related information. The views expressed in such contributions are the responsibility of the individual authors and do not imply the endorsement of the International Association of Law Libraries.

\section{MANUSCRIPT INFORMATION}

Manuscripts and any material intended for inclusion in the $I J L I$ should be addressed to the Editor, Mark Engsberg, who may be reached via email at mark.engsberg@emory.edu. Manuscripts are to be submitted in MS Word or WordPerfect as an attachment.

Single copy requests and current claims, should be sent to:

Mark Engsberg, IJLI Editor

Emory Law Library, 1301 Clifton Road

Atlanta, GA, 30322, USA

Tel.: (404)727-6983; Fax: (404)727-2202

mark.engsberg@emory.edu

All bibliographies should contain complete bibliographic information and follow The Chicago Manual of Style, 16th ed. (Chicago, 2003).

Book reviews and books for view should be sent directly to:

Thomas W. Mills, Book Review Editor

Cornell University Law Library

340B Myron Taylor Hall

Ithaca, NY 14853-4901, USA

Twm26@cornell.edu

\section{MEMBERSHIP AND SUBSCRIPTION INFORMATION}

Current information about the $I A L L$, its members and activities can be found at http://www.iall.org.

$I A L L$ membership includes subscription to the IJLI. Checks should be made out to the International Association of Law Libraries and sent to the Association's P.O. Box at the address above.

Individual: Student membership - US\$20; Personal membership - US\$95 (North America, the EU, EEA, Australia and New Zealand; US\$60 All other countries), Institutional membership US\$130.

Back issues of the $I J L I$ are available in hardcopy and in microfiche. Please contact William S. Hein \& Co., Inc., 2350 North Forest Rd., Getzville, NY 14068, USA, Tel.: (800) 828-7571 or (716) 8822600; Fax: (716) 883-8100; email: order@wshein.com.

Copyright by the International Association of Law Libraries.

Library of Congress Card No. 82-643460; ISSN 0731-1265. Printed in the United States. 


\section{CONTENTS}

EDITORIAL COMMENT

PRESIDENT'S REPORT

LIBRARIES AND THE RULE OF LAW: FINAL PROGRAM
Mark D. Engsberg vii

Mark D. Engsberg ix

xiii

\section{ARTICLES}

Argentine Constitutional Law. An Overview

Lucas S. Grosman 1

Welcome Comments Juan Carlos Valle Raleigh 5

The Impact of International Law on Domestic Judgments: The Influence of the Inter-American Court Of Human Rights in the Rulings of the Argentinean Supreme Court Regarding Crimes Against Humanity Agostina Allori 9

Reproductive Justice and the Rule of Law in Latin America Paola Bergallo 14

MERCOSUR: Southern Common Market

Dario Celaya Alvarez 27

Human Rights in Argentina: Its International Projection

Federico Villegas Beltrán 45

The Conception of Law and Legal Research

Matías Bailone 50

\section{BOOK REVIEWS}

Behind the Multilateral Trading System: Legal Indigenization and the WTO in Comparative Perspective Luis Acosta 53

Dictionary of International Human Rights Law Constance A. Johnson 55

Extraterritorial Application of Selected Human Rights Treaties

Theresa Papademetriou 56 
English/Spanish and Spanish/English Legal Dictionary \& Spanish-English Dictionary of Law and Business

Scott Rasmussen 58

International Criminal Procedure: The Interface of Civil Law and Common Law Legal Systems

Peter Roudik 60

INTERNATIONAL CALENDAR

Aslihan Bulut 62 